\title{
Intervention by a clinical pharmacist carried out at discharge of elderly patients admitted to the internal medicine department: influence on readmissions and costs
}

\author{
Andrea Lázaro Cebas ${ }^{*}$, José Manuel Caro Teller², Carmen García Muñoz², Carlos González Gómez³, \\ José Miguel Ferrari Piquero² , Carlos Lumbreras Bermejo ${ }^{3}$, José Antonio Romero Garrido ${ }^{4,5}$ and \\ Juana Benedí González ${ }^{5}$
}

\begin{abstract}
Background: Patient education on pharmacological treatment could reduce readmissions. Our objective was to carry out a pharmacist intervention focused on providing information about high-risk medications to chronic patients and to analyse its influence on readmissions and costs.

Methods: A single-centre study with an intervention group and a retrospective control group was conducted. The intervention was carried out in all polymedicated patients $\geq 65$ years who were admitted to internal medicine and signed the informed consent between June 2017 and February 2018. Patients discharged to nursing homes or longterm hospitals were excluded. The control group were all the patients who were admitted during the same months of 2014 who met the same inclusion criteria. The patients were classified according to the HOSPITAL score as having a low, intermediate, or high risk of potentially avoidable readmission. Outcome measures were 30-day readmission and cost data. To analyse the effect of the intervention on readmission, a logistic regression was performed.

Results: The study included 589 patients (286 intervention group; 303 control group). The readmission rate decreased from $20.13 \%$ to $16.43 \%$ in the intervention group [OR $=0.76095 \% \mathrm{Cl}(0.495-1.166) ; p=0.209)$ ]. The incremental cost for the intervention to prevent one readmission was $€ 3,091.19$, and the net cost saving was $€ 1,301.26$. In the intermediate- and high-risk groups, readmissions were reduced $10.91 \%$ and $10.00 \%$, and the net cost savings were $€ 3,3143.15$ and $€ 3,248.71$, respectively.
\end{abstract}

Conclusions: The pharmacist intervention achieved savings in the number of readmissions, and the net cost savings were greater in patients with intermediate and high risks of potentially avoidable readmission according to the HOSPITAL score.

Keywords: Pharmacists, Patient readmission, Aged, Polypharmacy, Cost analysis

*Correspondence: andrea.lazaro@carm.es

1 Pharmacy Management Department. Dirección General de Asistencia

Sanitaria, Servicio Murciano de Salud, Murcia, Spain

Full list of author information is available at the end of the article

\begin{abstract}
Background
The rise in life expectancy presents a significant challenge to health care systems in developed countries. As the population continues to age, the risk of chronic diseases associated with age and the demand for healthcare services are increasing [1].
\end{abstract}

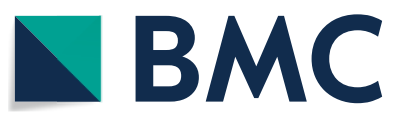

(c) The Author(s) 2022. Open Access This article is licensed under a Creative Commons Attribution 4.0 International License, which permits use, sharing, adaptation, distribution and reproduction in any medium or format, as long as you give appropriate credit to the original author(s) and the source, provide a link to the Creative Commons licence, and indicate if changes were made. The images or other third party material in this article are included in the article's Creative Commons licence, unless indicated otherwise in a credit line to the material. If material is not included in the article's Creative Commons licence and your intended use is not permitted by statutory regulation or exceeds the permitted use, you will need to obtain permission directly from the copyright holder. To view a copy of this licence, visit http://creativecommons.org/licenses/by/4.0/. The Creative Commons Public Domain Dedication waiver (http://creativeco mmons.org/publicdomain/zero/1.0/) applies to the data made available in this article, unless otherwise stated in a credit line to the data. 
Medication reconciliation and patient education about pharmacological treatment are recommended strategies for reducing medication errors during transitions of care [2-4]. However, when clinical pharmacists carry out these interventions in elderly patients, the results have been variable. The results of three meta-analyses indicate that medication reconciliation programmes performed by clinical pharmacists have reduced emergency department visits $[2,3,5]$, medication-related adverse event visits [3, 5], medication errors [2], and readmissions [3].

Elderly polymedicated patients with chronic diseases are particularly vulnerable to hospital readmissions for any cause $[4,6]$, but the risk of readmission may vary within this patient group. In fact, according to different models that predict readmissions, such other variables as the number of previous admissions and the length of hospital stay can impact readmission, as can comorbidities, age, and polypharmacy [7]. Among the different predictive models of potentially avoidable readmissions published, the HOSPITAL score is a model that has been validated to identify patients admitted to medical services who have high, intermediate, or low risk of potentially avoidable readmission at the time of hospital discharge $[8,9]$. In patients over 65 years, this model has good discriminatory power for patients with a high risk of potentially avoidable readmission as well as those with a high risk of general readmission [10].

In relation to polypharmacy, not all medications bring the same risk of hospital admission or readmission when errors associated with their use occur [4, 11]. For this reason, the members of the Institute for Safe Medication Practices in Spain published a list of high-alert medications for patients with chronic illnesses (HAMC list) to prioritize the implementation of effective interventions on medication safety [12].

Pharmacist interventions carried out in polymedicated elderly patients to improve pharmacotherapy and reduce readmission are heterogeneous in their nature and in their results. Furthermore, no studies have analysed whether interventions that aim to provide information about medications on the HAMC list to patients and caregivers could influence readmission or whether these interventions could be more effective in patients with a higher risk of potentially avoidable readmission.

The purpose of this study was to carry out a pharmacist intervention focused on providing information about medications on the HAMC list to polymedicated elderly patients admitted to the internal medicine ward. To analyse the impact of the intervention in this health service, a cost analysis was performed, and the influence on readmission rate was determined in the whole patient population and by subgroups of potentially avoidable readmission risk according to HOSPITAL score.

\section{Methods}

\section{Study design}

A single-centre study with an intervention group and a retrospective control group was carried out in a tertiary hospital where the internal medicine department staff treats patients in 4 independent hospitalization wards. The intervention was carried out for 9 months: June 2017 to February 2018.

\section{Participants}

The study included elderly patients ( $\geq 65$ years) who were polymedicated ( 5 or more chronic disease medications) and who had been admitted to one of the four internal medicine hospitalization wards during the study period. Patients with programmed admissions and patients who were discharged to nursing homes or long-term hospitals were excluded.

\section{Intervention group}

Patients admitted to one of the internal medicine hospitalization wards from June 2017 to February 2018 who met the inclusion criteria and signed the informed consent (IC) form were consecutively included. A clinical pharmacist who was integrated into the regular medical team carried out interventions on the patient's treatment at different times during the healthcare process.

\section{Control group}

Patients admitted to the same hospitalization ward over the same months of 2014 who met the inclusion criteria were included in the control group. As the patients were recruited retrospectively, an IC form was not required.

\section{Data collection}

The patients included in the study were divided into three groups according to HOSPITAL score: low risk of potentially avoidable readmission (0-4 points), intermediate risk (5-6 points), and high risk ( $\geq 7$ points). The HOSPITAL score was calculated from seven parameters: haemoglobin $(\mathrm{Hb})$ level $<12 \mathrm{~g} / \mathrm{dL}$ in the last laboratory test prior to discharge (1 point), discharge from the oncology service ( 2 points), sodium $<135 \mathrm{mEq} / \mathrm{L}$ in the last laboratory test prior to discharge (1 point), procedures carried out during hospitalization according to the International Classification of Diseases (ICD-9) (1 point), urgent/emergent admission (1 point), number of hospitalizations during the previous year (0-1: 0 points, 2-5: 2 points, $>5: 5$ points), and length of stay $>5$ days ( 2 points) [8].

The following variables were collected from both patient groups through their electronic medical records: demographics (sex and age); degree of dependence (independent or low dependence, moderate dependence, and severe or total dependence); 
comorbidities (cognitive impairment, heart failure, stroke, chronic pulmonary disease, chronic liver disease, chronic kidney disease (CKD), and diabetes); diagnosis on admission and readmission classified according to the following categories: heart disease, respiratory disease, kidney disease, gastrointestinal disease, neurological disease, liver or biliary disease, endocrine system (diabetes or electrolyte abnormalities), infection, neoplasia (solid or haematological), and other; number of chronic medications; and number of medications from the HAMC list prescribed at discharge. From the HAMC list, the following groups of medications were considered: antiplatelets, oral anticoagulants, nonsteroidal anti-inflammatory drugs (NSAIDs), central nervous system depressants (benzodiazepines and opioids), antiarrhythmic agents ( $\beta$-adrenergic blockers, digoxin, and amiodarone), insulin, oral hypoglycaemic agents, and diuretics (loop diuretics) [12]. In addition, based on a consensus between internal medicine and pharmacy departments, the following drugs and therapeutic groups were included: diltiazem and verapamil (antiarrhythmic agents), thiazides (diuretics), and renin-angiotensin system inhibitors (angiotensin-converting enzyme inhibitors (ACEIs) or angiotensin receptor blockers (ARBs)).

\section{Pharmacist intervention}

At admission: Interview with the patient and/or main caregiver and medication reconciliation.

During hospitalization: Pharmacotherapeutic followup (validation of the prescriptions).

On discharge: Interview with the patient and/or main caregiver, including an educational intervention regarding postdischarge treatment (written treatment plan and written information about HAMC): information on changed dose, medication initiations or discontinuations and the detection and management of possible adverse events associated with the different HAMC.

At home (phone call follow-up): A phone call at 7 and 21 days after discharge, with completion of a questionnaire to measure the degree of knowledge of patients and/or their main caregivers regarding HAMC.

The questionnaire used to measure the patient's knowledge of HAMC was a validated questionnaire of 11 questions. This questionnaire assesses knowledge in four dimensions: therapeutic objective (therapeutic indication and effectiveness), process of use (dosage, regimen, administration, and duration of treatment), safety (adverse reactions, precautions, contraindications, and interactions), and storage [13]. The answers to the questions were categorized by the interviewing pharmacist as "is aware" or "is not aware" according to the information provided by the patient or caregiver.

\section{Outcome measures}

Readmission was defined as all-cause 30-day hospital readmission. The readmission rate was determined in the whole patient population and in the 3 different categories of potentially avoidable readmission risk defined by the HOSPITAL score.

To analyse the cost of the intervention, the absolute risk reduction (ARR) of the readmission rate from the control to the intervention group and the number needed to treat (NNT) were calculated. The costs considered to do the analysis were a median cost per admission in patients older than 65 years of $€ 4,392.45$ [14] and a median annual clinical pharmacist salary of $€ 45,749.58$ [15]. The patient population who could be recipients of the intervention over 1 year was estimated to be 400 .

The cost analysis was performed for all patients and for the patients in the 3 different categories of potentially avoidable readmission risk defined by the HOSPITAL score.

\section{Statistical Analysis}

A descriptive analysis of baseline characteristics was performed on the patients in the control and intervention groups. Categorical and quantitative variables were tested by the $\chi^{2}$ test or Fisher's exact test, and continuous variables were assessed using the nonparametric MannWhitney-Wilcoxon U tests, as stipulated by the ShapiroWilk normality test. Categorical variables are presented as number and percentage, and continuous variables are presented as median and interquartile range (IQR).

A binary logistic regression was performed to analyse the effect of the intervention on readmission. In the multivariate analysis, all variables with statistically significant differences $(p<0.05)$ between the control and intervention groups were included. The results are expressed as odds ratio (OR) with $95 \%$ confidence interval $(95 \% \mathrm{CI})$.

Statistical analysis was carried out using Stata ${ }^{\circledR} 16$ statistical software (StataCorp. 2019. Stata Statistical Software: Release 16. College Station, TX: StataCorp LLC). A significance level of $5 \%$ was used in this study.

\section{Results}

A total of 589 patients were included in the present study: 286 patients in the intervention group and 303 in the control group (Fig. 1).

The baseline characteristics of both groups are listed in Table 1. All variables measured were comparable ( $p>0.05)$ except age (higher in the intervention group) and CKD (more prevalent in the intervention group). 

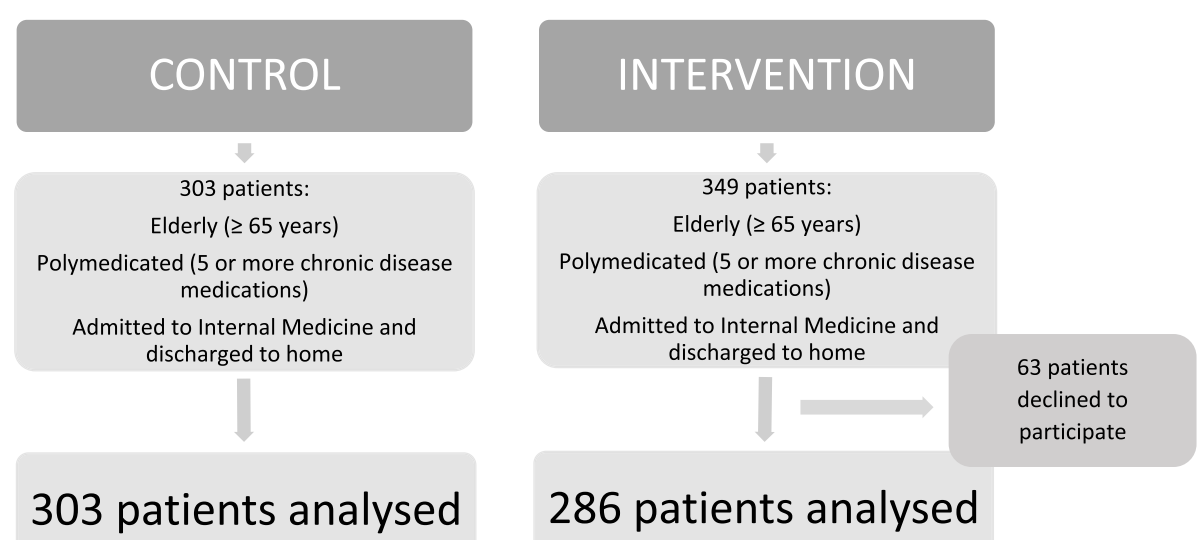

286 patients analysed

Fig. 1 Flow chart

Of the 572 follow-up phone calls that could be made to the 286 patients in the intervention group, 491 were carried out. Two hundred sixty-three (53.56\%) were made 7 days after discharge, and 228 (46.44\%) were made on day 21 . All possible phone calls could not be made because of patient readmission $(60.73 \%, n=50)$ and the inability to contact the patient or caregiver $(38.27 \%$, $n=31$ ).

The number of phone calls answered by the patients was $192(39.10 \%)$. In $82.81 \%(n=159)$ of them, the patients reported independently taking and organizing their medication without assistance. The other phone calls $(60.90 \%, n=299)$ were answered by caregivers who prepared and/or administered the patient treatment. The distribution of the patient's knowledge in each of the dimensions of the questionnaire by HAMC group is shown in Table 2. No questions were asked about NSAIDs, as none of the patients were on NSAID treatment.

The 30-day readmission rate was $20.13 \%(n=61)$ in the control group and $16.43 \%(n=47)$ in the intervention group $[\mathrm{OR}=0.78095 \% \mathrm{CI}(0.512-1.188) ; p=0.247)]$. The effect of the intervention was not modified in the multivariate analysis when it was adjusted by age and CKD $[\mathrm{OR}=0.76095 \% \mathrm{CI}(0.495-1.166) ; p=0.209)]$ (Table 3).

The most frequent diagnoses at readmission in the intervention and control groups were those related to heart disease (41.94\% control group vs. $28.26 \%$ intervention group) and infection (27.42\% control group vs. $32.61 \%$ control group). Readmissions related to heart disease were 13.68 percentage points less common in the intervention group than the control group.

In the subgroup of patients with a low risk of potentially avoidable readmission, the 30 -day readmission rate was similar between the control and intervention groups $(11.89 \%$ vs $12.43 \%)$. In the subgroups of patients with intermediate and high risk of potentially avoidable readmission, reductions in readmission rates were observed in the intervention group (Table 4). All the patients from the intervention and control groups, including those in the intervention group who did not complete the phone call follow-up, were included in the analysis. The cost analysis was performed in the whole patient sample and in the patients with intermediate or high risk of potentially avoidable readmission. The net cost savings per readmission adverted were $€ 1,301.26$ in the whole set of patients, $€ 3,343.15$ in the group with intermediate risk of potentially avoidable readmission and $€ 3,248.71$ in the high-risk group. A summary of the cost analysis is given in Table 4.

\section{Discussion}

In this study, the pharmacist intervention achieved cost savings, and the absolute reduction in readmission rate was approximately $4 \%$. These results were in accordance with previous publications [16-21]. In some published studies, pharmacist interventions did not significantly decrease readmission [16, 18-22], while other studies that evaluated the effect of this type of intervention found statistically significant effects [23-26].

Our pharmacist intervention was focused on providing information on medications with a high risk of adverse events associated with erroneous use in elderly patients with chronic diseases [12]. The degree of patient knowledge of HAMC varied widely between the different questionnaire dimensions. In the dimension related to the process of use, a mean of more than $95.00 \%$ of patients or caregivers knew the answers, whereas in 
Table 1 Patient characteristics at baseline

\begin{tabular}{|c|c|c|c|c|}
\hline & $\begin{array}{l}\text { Total } \\
n=589\end{array}$ & $\begin{array}{l}\text { Control } \\
n=303\end{array}$ & $\begin{array}{l}\text { Intervention } \\
n=286\end{array}$ & $p$ value \\
\hline & No. (\%) & & No. (\%) & \\
\hline Sex (male) & $259(43.97)$ & $131(43.23)$ & $128(44.76)$ & 0.710 \\
\hline Age, years (median, IQR) & $83[78-87]$ & $83[77-86]$ & 84 [79-88] & 0.0044 \\
\hline Length of stay, days (median, IQR) & $8[5-12]$ & $8[5-12]$ & $7[5-11]$ & 0.055 \\
\hline No. of medications at discharge (median, IQR) & $9[7-11]$ & $9[7-11]$ & $9[7-11]$ & 0.3320 \\
\hline No. of HAMC list drugs at discharge (median IQR) & $4[3-5]$ & $4[3-4]$ & $4[3-5]$ & 0.5207 \\
\hline Degree of dependence & & & & 0.199 \\
\hline Independent or low dependence & $361(61.29)$ & $179(59.08)$ & $182(63.64)$ & \\
\hline Moderate dependence & $168(28.52)$ & $96(31.68)$ & $72(25.17)$ & \\
\hline Severe or total dependence & $60(10.19)$ & $28(9.24)$ & $32(11.19)$ & \\
\hline \multicolumn{5}{|l|}{ Comorbidities } \\
\hline No. of comorbidities (median, IQR) & $2[1-3]$ & $2[1,2]$ & $2[1-3]$ & 0.3490 \\
\hline Cognitive impairment & $118(20.03)$ & $55(18.15)$ & $63(22.03)$ & 0.240 \\
\hline Heart failure & $233(39.56)$ & $113(37.29)$ & $120(41.96)$ & 0.247 \\
\hline Chronic pulmonary disease & $225(38.20)$ & $117(38.61)$ & $108(37.76)$ & 0.832 \\
\hline Chronic kidney disease & $141(23.94)$ & $61(20.13)$ & $80(27.97)$ & 0.026 \\
\hline Chronic liver disease & $30(5.09)$ & $18(5.94)$ & $12(4.20)$ & 0.336 \\
\hline Diabetes & $241(40.92)$ & $128(42.24)$ & $113(39.51)$ & 0.500 \\
\hline Stroke & $77(13.07)$ & $41(13.53)$ & $36(12.59)$ & 0.734 \\
\hline Primary admission diagnosis & & & & 0.189 \\
\hline Heart disease & $187(31.75)$ & $103(33.99)$ & $84(29.37)$ & \\
\hline Respiratory disease & $57(9.68)$ & $30(9.90)$ & $27(9.44)$ & \\
\hline Kidney disease & $5(0.85)$ & $4(1.32)$ & $1(0.35)$ & \\
\hline Gastrointestinal disease & $28(4.75)$ & $17(5.61)$ & $11(3.85)$ & \\
\hline Neurological disease & $23(3.90)$ & $14(4.62)$ & $9(3.15)$ & \\
\hline Liver or biliary disease & $14(2.38)$ & $5(1.65)$ & $9(3.15)$ & \\
\hline Endocrine system (diabetes or electrolyte abnormalities) & $10(1.70)$ & $5(1.65)$ & $5(1.75)$ & \\
\hline Infection & $197(33.45)$ & $86(28.38)$ & $111(38.81)$ & \\
\hline Neoplasia (solid or haematological) & $15(2.55)$ & $7(2.31)$ & $8(2.80)$ & \\
\hline Others & $53(9.00)$ & $32(10.56)$ & $21(7.34)$ & \\
\hline Risk of potentially avoidable readmission (HOSPITAL score) & & & & 0.806 \\
\hline Low & $362(61.46)$ & $185(61.06)$ & $177(61.89)$ & \\
\hline Intermediate & $189(32.09)$ & $100(33.00)$ & $89(31.12)$ & \\
\hline High & $38(6.45)$ & $18(5.94)$ & $20(6.99)$ & \\
\hline
\end{tabular}

HAMC high-alert medications for patients with chronic illnesses

the safety block of questions, only a mean of $13.00 \%$ were aware of the relevant information. One explanation might be that at the time of hospital discharge, both patients and caregivers tend to focus on basic treatment information (dosage, regimen, administration, and duration of treatment), but knowledge of medication safety is part of an advanced understanding of medication management, so the time of hospital discharge might not be the best time to share this information with patients and caregivers.
According to published studies, pharmacist interventions that focus on increasing the knowledge of elderly patients with chronic diseases on high-risk medications had better results when they were combined with other measures to improve care coordination and comprehensive patient care $[19,23-26]$. In our study, the pharmacists could not collaborate with care coordinators, primary care physicians or community pharmacists, so the HAMC safety information was shared at hospital discharge instead of at a time more conducive 
Table 2 Patients' distribution of knowledge in each of the dimensions of the questionnaire by HAMC group

\begin{tabular}{|c|c|c|c|c|c|c|c|c|}
\hline & $\begin{array}{l}\text { Antiplatelets } \\
(n=25) \\
\text { Is aware, No. } \\
(\%)\end{array}$ & $\begin{array}{l}\text { Antiarrhythmic } \\
\text { agents }(n=46) \\
\text { Is aware, No. (\%) }\end{array}$ & $\begin{array}{l}\text { Oral } \\
\text { anticoagulants } \\
(n=99) \\
\text { Is aware, No. (\%) }\end{array}$ & $\begin{array}{l}\text { Oral } \\
\text { hypoglycaemic } \\
\text { agents }(n=30) \\
\text { Is aware, No. (\%) }\end{array}$ & $\begin{array}{l}\text { ACEls or } \\
\text { ARBs }(n=67) \\
\text { Is aware, No. } \\
(\%)\end{array}$ & $\begin{array}{l}\text { CNS } \\
\text { depressants } \\
(n=51) \\
\text { Is aware, No. } \\
(\%)\end{array}$ & $\begin{array}{l}\begin{array}{l}\text { Diuretics } \\
(n=131)\end{array} \\
\text { Is aware, No. } \\
(\%)\end{array}$ & $\begin{array}{l}\text { Insulin } \\
(n=42) \\
\text { Is aware, No. } \\
(\%)\end{array}$ \\
\hline \multicolumn{9}{|c|}{ Therapeutic objective } \\
\hline $\begin{array}{l}\text { What is the } \\
\text { therapeutic } \\
\text { indication of } \\
\text { this medica- } \\
\text { tion? }\end{array}$ & $20(80.00)$ & 34 (73.91) & $85(85.86)$ & $28(93.33)$ & $47(70.15)$ & $48(94.12)$ & 111 (84.73) & $42(100.00)$ \\
\hline $\begin{array}{l}\text { How do you } \\
\text { know if the } \\
\text { medication is } \\
\text { effective? }\end{array}$ & $7(28.00)$ & $28(60.87)$ & $58(58.59)$ & $15(50.00)$ & $44(65.67)$ & $40(78.43)$ & $110(83.97)$ & $40(95.24)$ \\
\hline \multicolumn{9}{|l|}{ Process of use } \\
\hline $\begin{array}{l}\text { What is the } \\
\text { dosage of this } \\
\text { medication that } \\
\text { you must take? }\end{array}$ & $25(100.00)$ & $40(86.96)$ & 93 (93.94) & $30(100.00)$ & $62(92.54)$ & $48(94.12)$ & $124(94.66)$ & $42(100.00)$ \\
\hline $\begin{array}{l}\text { What is the } \\
\text { regimen for } \\
\text { taking this } \\
\text { medication? }\end{array}$ & $25(100.00)$ & $42(91.30)$ & $94(94.95)$ & $30(100.00)$ & $63(94.03)$ & $47(92.16)$ & $125(95.42)$ & $42(100.00)$ \\
\hline $\begin{array}{l}\text { What is the } \\
\text { treatment } \\
\text { duration for this } \\
\text { medication? }\end{array}$ & $25(100.00)$ & $42(91.30)$ & $94(94.95)$ & $30(100.00)$ & $63(94.03)$ & $47(92.16)$ & $126(96.18)$ & $42(100.00)$ \\
\hline $\begin{array}{l}\text { How should } \\
\text { you administer } \\
\text { this medica- } \\
\text { tion? }\end{array}$ & $25(100.00)$ & $42(91.30)$ & $94(94.95)$ & $29(96.67)$ & $63(94.03)$ & 47 (92.16) & $126(96.18)$ & $42(100.00)$ \\
\hline \multicolumn{9}{|l|}{ Safety } \\
\hline $\begin{array}{l}\text { Should you take } \\
\text { any precautions } \\
\text { when you take } \\
\text { this medica- } \\
\text { tion? Which } \\
\text { ones? }\end{array}$ & $10(40.00)$ & $11(23.91)$ & $60(60.61)$ & $3(10.00)$ & $5(7.46)$ & $11(21.57)$ & 39 (29.77) & $16(38.10)$ \\
\hline $\begin{array}{l}\text { Do you know } \\
\text { the adverse } \\
\text { reactions of this } \\
\text { medication? }\end{array}$ & $10(40.00)$ & $5(10.87)$ & $39(39.39)$ & $4(13.33)$ & $5(7.46)$ & $8(15.69)$ & $7(5.34)$ & $15(35.71)$ \\
\hline $\begin{array}{l}\text { What special } \\
\text { situations } \\
\text { or health } \\
\text { problems } \\
\text { contraindicate } \\
\text { the use of this } \\
\text { medication? }\end{array}$ & $2(8.00)$ & $2(4.35)$ & $6(6.06)$ & $2(6.67)$ & $2(2.99)$ & $1(1.96)$ & $3(2.29)$ & $6(14.29)$ \\
\hline $\begin{array}{l}\text { Which other } \\
\text { medications } \\
\text { or food should } \\
\text { you avoid while } \\
\text { you are taking } \\
\text { this medica- } \\
\text { tion? }\end{array}$ & $1(4.00)$ & $1(2.17)$ & $6(6.06)$ & $2(6.67)$ & $1(1.49)$ & $1(1.96)$ & $1(0.76)$ & $0(0.00)$ \\
\hline \multicolumn{9}{|l|}{ Storage } \\
\hline $\begin{array}{l}\text { Where should } \\
\text { you store this } \\
\text { medication? }\end{array}$ & $25(100.00)$ & $42(91.30)$ & $86(86.87)$ & $29(96.67)$ & $67(100.00)$ & $44(86.27)$ & 119 (90.84) & $40(95.24)$ \\
\hline
\end{tabular}

HAMC high-alert medications for patients with chronic illnesses, ACEls angiotensin-converting enzyme inhibitors, ARBs angiotensin receptor blockers, CNS central nervous system 
Table 3 Estimation of the pharmacist intervention effect on readmission after adjustment for age and chronic kidney disease

\begin{tabular}{llll}
\hline & OR & $\mathbf{9 5 \% ~ C l}$ & $\boldsymbol{p}$ value \\
\hline Pharmacist intervention & 0.760 & $0.495-1.166$ & 0.209 \\
Age, years & 0.977 & $0.948-1.007$ & 0.136 \\
Chronic kidney disease & 1.891 & $1.193-2.998$ & 0.007 \\
\hline
\end{tabular}

to effective communication, which would have enabled both patient and caregiver to better understand the information.

Readmission due to heart disease was the diagnosis that was most reduced by the intervention. This may be because, within the readmission diagnoses, decompensation of heart failure is the condition that best lends itself to prevention through proper knowledge and management of the different drugs on the HAMC list (mainly diuretics but also ACEIs, ARBs, and antiarrhythmic agents) [27].

The net cost saving of the intervention per readmission adverted was $€ 1,301.26$. Extrapolated to the United States, considering a median cost per admission in patients older than 65 years of $\$ 14,420$ [28] and a median annual clinical pharmacist salary of $\$ 128,090$ [29], the net cost saving of the intervention per readmission adverted would be $\$ 5,473.93$. Given that the patients included in this study suffered from chronic and multiple diseases, readmissions are relevant not only because of their health care costs but also because of their impact on the patient's functional status, quality of life, morbidity, and mortality [30].

The group of patients selected for the intervention in this study were already at high risk of readmission [4,
6]. The HOSPITAL predictive model is a valid and easyto-apply tool for selecting, within this high-risk patient group, those who could benefit more from such a pharmacist intervention.

Several limitations of this study should be noted. Due to the limited time the pharmacist intervention was carried out, too few patients were included in the study to demonstrate the benefit of the intervention on readmission with adequate power. Even so, the percentage readmission reduction was comparable to that in previous studies. Other limitations were the single-centre nature and the use of a retrospective control group. Despite the use of a retrospective control group, patient characteristics at baseline between the control and intervention groups were comparable.

The study had several strengths. First, the intervention was focused on a target population recognized by healthcare institutions in their attempt to reduce readmissions. Second, the intervention was focused on improving patient safety by providing information about medications with a high risk of producing adverse events in chronic patients.

\section{Conclusions}

The pharmacist intervention implemented in this study achieved cost savings and reduced the frequency of readmissions. The net cost savings of the intervention were the best in the selection of patients with intermediate and high risk of potentially avoidable readmission. The HOSPITAL score has been demonstrated to be a valid and easy-to-apply tool for selecting patients who could benefit the most from such pharmacist interventions.

Table 4 Cost analysis

\begin{tabular}{|c|c|c|c|c|c|c|}
\hline & \multicolumn{2}{|l|}{ Total } & \multicolumn{2}{|c|}{$\begin{array}{l}\text { Intermediate risk of potentially } \\
\text { avoidable readmission }\end{array}$} & \multicolumn{2}{|c|}{$\begin{array}{l}\text { High risk of potentially avoidable } \\
\text { readmission }\end{array}$} \\
\hline & Control $(n=303)$ & $\begin{array}{l}\text { Intervention } \\
(n=286)\end{array}$ & Control $(n=100)$ & $\begin{array}{l}\text { Intervention } \\
(n=89)\end{array}$ & Control $(n=18)$ & Intervention $(n=20)$ \\
\hline $\begin{array}{l}\text { 30-day readmissions, } \\
\text { No. }(\%)\end{array}$ & $61(20.13)$ & $47(16.43)$ & $30(30.00)$ & $17(19.10)$ & $9(50.00)$ & $8(40.00)$ \\
\hline $\begin{array}{l}\text { ARR of 30-day read- } \\
\text { mission (\%) }\end{array}$ & 3.70 & & 10.90 & & 10.00 & \\
\hline NNT & 27 & & 9 & & 10 & \\
\hline $\begin{array}{l}\text { Incremental cost for } \\
\text { the intervention to } \\
\text { prevent one read- } \\
\text { mission }^{\text {a }(€)}\end{array}$ & $3,091.19$ & & $1,049.30$ & & $1,143.74$ & \\
\hline Cost saving $^{\mathrm{b}}(€)$ & $1,301.26$ & & $3,343.15$ & & $3,248.71$ & \\
\hline
\end{tabular}

$A R R$ absolute risk reduction NNT number needed to treat

${ }^{\text {a }}$ NNT $\times$ Cost of the intervention per patient $[€ 45,749.58$ (median annual clinical pharmacist salary)/400 (patient population that could be recipients of the intervention over 1 year]

${ }^{\mathrm{b}}$ Incremental cost for the intervention to prevent one readmission - Cost per admission $(€ 4,392.45)$ 


\section{Abbreviations}

HAMC: High-alert medications for patients with chronic illnesses; IC: Informed consent; ICD: International Classification of Diseases; CKD: Chronic kidney disease; NSAIDs: Nonsteroidal anti-inflammatory drugs; ACEls: Angiotensinconverting enzyme inhibitors; ARBs: Angiotensin receptor blockers; ARR: Absolute risk reduction; NNT: Number needed to treat.

\section{Acknowledgements}

Sara Ortiz and Siria Pablos are acknowledged for providing database designing assistance. The Unit of Investigation and Scientific Support from Instituto de Investigación i+12 (Hospital Universitario 12 de Octubre) is acknowledged for data analysis assistance.

\section{Authors' contributions}

Study concept and design: Lázaro Cebas A., Caro Teller J.M., García Muñoz C., González Gómez C., Romero Garrido J.A., Benedí González J. Patients' selection and clinical data acquisition: Lázaro Cebas A., Caro Teller J.M., García Muñoz C. Statistical analysis and interpretation of data: Lázaro Cebas A. Writing of the manuscript: Lázaro Cebas A. Critical revision of the manuscript for relevant intellectual content: Lázaro Cebas A., Caro Teller J.M., García Muñoz C., González Gómez C., Ferrari Piquero J.M., Lumbreras Bermejo C., Romero Garrido J.A., Benedí González J. Supervision and visualization: Lázaro Cebas A., Caro Teller J.M., García Muñoz C., González Gómez C., Romero Garrido J.A., Benedí González J. All authors read and approved the final manuscript.

\section{Funding}

This study was supported by Mapfre Foundation (Primitivo de Vega grant, 2016).

\section{Availability of data and materials}

Data will be available on request to the corresponding author due to privacy/ ethical restrictions. E-mail address: andrea.lazaro@carm.es.

\section{Declarations}

\section{Ethics approval and consent to participate}

This research was performed in accordance with the Ethical Principles for Medical Research Involving Human Subjects (Declaration of Helsinki). The study was approved by the Ethics Committee of Clinical Investigation (Comité Ético de Investigación Clínica (CEIC)) from 12 de Octubre University Hospital, which waived the requirement of informed consent to the control group as data were obtained retrospectively (Reference CEIC number 17/087). Informed consent was signed by the patients included in the intervention group.

\section{Consent for publication}

Not applicable

\section{Competing interests}

The authors declare that they have no competing interests.

\section{Author details}

${ }^{1}$ Pharmacy Management Department. Dirección General de Asistencia Sanitaria, Servicio Murciano de Salud, Murcia, Spain. ${ }^{2}$ Pharmacy Department. Hospital, Universitario 12 de Octubre, Madrid, Spain. ${ }^{3}$ Servicio de Medicina Interna Hospital Universitario 12 de Octubre, Madrid, Spain. ${ }^{4}$ Pharmacy Department Hospital, Universitario La Paz, Madrid, Spain. ${ }^{5}$ Pharmacology Department. Facultad de Farmacia, Universidad Complutense, Madrid, Spain.

Received: 1 July 2021 Accepted: 2 February 2022

Published online: 09 February 2022

\section{References}

1. Finlayson K, Chang AM, Courtney MD, Edwards HE, Parker AW, Hamilton $K$, et al. Transitional care interventions reduce unplanned hospital readmissions in high-risk older adults. BMC Health Serv Res. 2018;18:956.

2. De Oliveira GS, Castro-Alves LJ, Kendall MC, McCarthy R. Effectiveness of Pharmacist Intervention to Reduce Medication Errors and Health-Care
Resources Utilization After Transitions of Care: A Meta-analysis of Randomized Controlled Trials. J Patient Saf. 2017. https://doi.org/10.1097/PTS. 0000000000000283.

3. Mekonnen AB, McLachlan AJ, Brien JE. Effectiveness of pharmacistled medication reconciliation programmes on clinical outcomes at hospital transitions: a systematic review and meta-analysis. BMJ Open. 2016;6:e010003.

4. Linkens AEMJH, Milosevic V, van der Kuy PHM, Damen-Hendriks VH, MestresGonzalvo C, Hurkens KPGM. Medication-related hospital admissions and readmissions in older patients: an overview of literature. Int J Clin Pharm. 2020;42(5):1243-51.

5. Renaudin P, Boyer L, Esteve M-A, Bertault-Peres P, Auquier P, Honore S. Do pharmacist-led medication reviews in hospitals help reduce hospital readmissions? A systematic review and meta-analysis: Pharmacist-led medication reviews and hospital readmissions. $\mathrm{Br} J$ Clin Pharmacol. 2016;82:1660-73.

6. Maher RL, Hanlon J, Hajjar ER. Clinical consequences of polypharmacy in elderly. Expert Opin Drug Saf. 2014;13:57-65.

7. Zhou H, Della PR, Roberts P, Goh L, Dhaliwal SS. Utility of models to predict 28-day or 30-day unplanned hospital readmissions: an updated systematic review. BMJ open. 2016;6:e011060.

8. Donzé J, Aujesky D, Williams D, Schnipper JL. Potentially Avoidable 30-Day Hospital Readmissions in Medical Patients: Derivation and Validation of a Prediction Model. JAMA Intern Med. 2013;173:632.

9. Donzé JD, Williams MV, Robinson EJ, Zimlichman E, Aujesky D, Vasilevskis EE, et al. International Validity of the HOSPITAL Score to Predict 30-Day Potentially Avoidable Hospital Readmissions. JAMA Intern Med. 2016;176:496

10. Burke RE, Schnipper JL, Williams MV, Robinson EJ, Vasilevskis EE, Kripalani S, et al. The HOSPITAL Score Predicts Potentially Preventable 30-Day Readmissions in Conditions Targeted by the Hospital Readmissions Reduction Program. Medical Care. 2017;55(3):285-90.

11. Cabré M, Elias L, Garcia M, Palomera E, Serra-Prat M. Hospitalizaciones evitables por reacciones adversas a medicamentos en una unidad geriátrica de agudos. Análisis de 3.292 pacientes. Med Clínica. 2018;150(6):209-14.

12. Otero MJ, Moreno-Gómez AM, Santos-Ramos B, Agra Y. Developing a list of high-alert medications for patients with chronic diseases. Eur J Intern Med. 2014:25:900-8.

13. García Delgado P, Gastelurrutia Garralda MÁ, Baena Parejo MI, Fisac Lozano F, Martínez MF. Validación de un cuestionario para medir el conocimiento de los pacientes sobre sus medicamentos. Aten Primaria. 2009:41:661-8

14. Portal Estadístico. Área de Inteligencia de Gestión. Ministerio de Sanidad. Gobierno de España. Registro de Actividad de Atención Especializada RAE-CMBD. SNS.Consulta interactiva del SNS. Accessed 12 Mar 2021.

15. Instituto Nacional de Gestión Sanitaria - Retribuciones. Retribuciones INGESA Primer semestre 2019. Accessed 12 Mar 2021.

16. Kilcup M, Schultz D, Carlson J, Wilson B. Postdischarge pharmacist medication reconciliation: Impact on readmission rates and financial savings. J Am Pharm Assoc. 2013;53:78-84.

17. Pellegrin KL, Krenk L, Oakes SJ, Ciarleglio A, Lynn J, Mclnnis T, et al. Reductions in Medication-Related Hospitalizations in Older Adults with Medication Management by Hospital and Community Pharmacists: A Quasi-Experimental Study. J Am Geriatr Soc. 2017;65:212-9.

18. Gillespie U, Alassaad A, Henrohn D, Garmo H, Hammarlund-Udenaes M, Toss $\mathrm{H}$, et al. A comprehensive pharmacist intervention to reduce morbidity in patients 80 years or older: a randomized controlled trial. Arch Intern Med. 2009;169:894-900.

19. Ravn-Nielsen LV, Duckert M-L, Lund ML, Henriksen JP, Nielsen ML, Eriksen CS, et al. Effect of an In-Hospital Multifaceted Clinical Pharmacist Intervention on the Risk of Readmission: A Randomized Clinical Trial. JAMA Intern Med. 2018:178:375.

20. Graabaek T, Hedegaard U, Christensen MB, Clemmensen MH, Knudsen T, Aagaard L. Effect of a medicines management model on medicationrelated readmissions in older patients admitted to a medical acute admission unit-A randomized controlled trial. J Eval Clin Pract. 2019;25:88-96.

21. March KL, Peters MJ, Finch CK, Roberts LA, McLean KM, Covert AM, et al. Pharmacist Transition-of-Care Services Improve Patient Satisfaction and Decrease Hospital Readmissions. J Pharm Pract. 2020. https://doi.org/10. $1177 / 0897190020958264$. 
22. Sanchez GM, Douglass MA, Mancuso MA. Revisiting Project Re-Engineered Discharge (RED): The Impact of a Pharmacist Telephone Intervention on Hospital Readmission Rates. Pharmacother J Hum Pharmacol Drug Ther. 2015;35:805-12.

23. Arnold ME, Buys L, Fullas F. Impact of pharmacist intervention in conjunction with outpatient physician follow-up visits after hospital discharge on readmission rate. Am J Health Syst Pharm. 2015;72(Suppl 1):36-42.

24. Cheen MHH, Goon CP, Ong WC, Lim PS, Wan CN, Leong MY, et al. Evaluation of a care transition program with pharmacist-provided home-based medication review for elderly Singaporeans at high risk of readmissions. Int J Qual Health Care. 2016;29:200-5.

25. Bae-Shaaw YH, Eom H, Chun RF, Steven FD. Real-world evidence on impact of a pharmacist-led transitional care program on 30- and 90-day readmissions after acute care episodes. Am J Health Syst Pharm. 2020;77:535-45.

26. Miller D, Ramsey M, L'Hommedieu TR, Verbosky L. Pharmacist-led transitions-of-care program reduces 30-day readmission rates for Medicare patients in a large health system. Am J Health Syst Pharm. 2020;77:972-8.

27. Lee KK, Thomas RC, Tan TC, Leong TK, Steimle A, Go AS. The Heart Failure Readmission Intervention by Variable Early Follow-up (THRIVE) Study: A Pragmatic Randomized Trial. Circ Cardiovasc Qual Outcomes. 2020. https://doi.org/10.1161/CIRCOUTCOMES.120.006553.

28. Healthcare Cost and Utilization Project Fast Stats. Agency for Healthcare Research and Quality. Trends in Hospital Costs/Utilization - HCUP Fast Stats. Accessed 10 Mar 2021

29. U.S. Bureau of Labor Statistics. Pharmacists : Occupational Outlook Handbook: : U.S. Bureau of Labor Statistics. Accessed 12 Mar 2021.

30. Zuckerman RB, Sheingold SH, Orav EJ, Ruhter J, Epstein AM. Readmissions, Observation, and the Hospital Readmissions Reduction Program. N Engl J Med. 2016;374:1543-51.

\section{Publisher's Note}

Springer Nature remains neutral with regard to jurisdictional claims in published maps and institutional affiliations.

- fast, convenient online submission

- thorough peer review by experienced researchers in your field

- rapid publication on acceptance

- support for research data, including large and complex data types

- gold Open Access which fosters wider collaboration and increased citations

- maximum visibility for your research: over 100M website views per year

At BMC, research is always in progress.

Learn more biomedcentral.com/submissions 